Acta vet. scand. $1984,25,164-186$.

From the Department of Internal Medicine I, Division of Parasitology, Norwegian College of Veterinary Medicine, Oslo.

\title{
EPIDEMIOLOGICAL INVESTIGATIONS OF TRICHOSTRONGYLID INFECTIONS IN YOUNG CATTLE IN DIFFERENT PARTS OF NORWAY
}

\author{
By \\ Jorun Tharaldsen and Oddvar Helle
}

\begin{abstract}
THARALDSEN, JORUN and ODDVAR HELLE: Epidemiological investigations of trichostrongylid infections in young cattle in different parts of Norway. Acta vet. scand. 1984, 25, 164-186. - The occurrence of trichostrongylid nematodes in young cattle was studied in relation to climate and geographical location, by examination of herbage and faecal samples from 8 farms in 7 different regions in Norway, during 3 consecutive summers. Species of Ostertagia and Cooperia were dominant. Infective larvae, especially those of Ostertagia, were able to survive the winter in the pasture to a great extent in all the areas studied. The spring larval counts varied considerably from place to place, and from year to year, but were often at fairly high levels. This confirms previous findings that the larvae which overwinter on the pasture may be a major cause of losses. Overt clinical disease, however, was only seen at 1 farm during this investigation.

The large number of larvae often seen in the autumn seems to be of less significance as a cause of disease, due to the late appearance, but is of major importance as a source of the larvae which survive the winter in the pasture and infect young cattle the following spring.

There was no obvious correlation between pasture larval counts and the climate, except that there seemed to be higher counts in the warmer parts of the country, where the grazing season is also longer. The only place were both faecal egg counts and larval counts in the herbage were consistently low, was in the very far north.
\end{abstract}

climate; Cooperia sp p.; herbage; larvae;

nematodes; Ostertagia spp.; survival.

Previous studies have shown that trichostrongylid nematodes may cause problems in young cattle during their first grazing season in Norway (Tharaldsen 1970, 1976, Helle \& Tharaldsen 1976). These observations were limited to one geographic area in the south-eastern part of the country. There were indications from practising veterinarians and farmers, however, that the problem was not restricted to that particular region. 
It is well known that climatic factors are important for the development and survival of the free-living stages of these nematodes (Levine 1963, Pandey 1972 a, b, Persson 1974). Considerable climatic differences exist between the various parts of Norway, from the south to the north (between $58^{\circ}$ and $71^{\circ}$ Northern Latitude), from the wet, western coastal regions to dry, inland areas, and from lowland to alpine, barren altitudes. As a result of these differences, one would also expect variations in the occurrence of the parasites. This investigation was therefore instigated in order to obtain more precise information on the epidemiological differences between the various regions.

The investigation is based upon material collected from 8 farms in 7 different geographical regions in Norway, among these being Finnmark, which probably has the most northern cattle population in the world. The material consisted of pasture larval counts and faecal egg counts from young cattle grazing permanent pastures. This investigation was part of a 3 year inter-Nordic research project on gastrointestinal nematodes in cattle; the major results from all the participating countries have been presented in a joint final report (Nansen 1981).

\section{MATERIALS AND METHODS}

Th e f a r m s. The locations of the farms are shown in Fig. 1. The farms were either research farms or agricultural schools farms. They were selected as being representative of most of the climatic conditions prevalent in areas where cattle are raised in Norway.

The c li m a t e. A short description is given in Table 1. Five-day sums of precipitation and five-day means of temperature are shown in Fig. 2. Table 2 shows data on temperature and precipitation during the summer months, and the yearly means, in addition to information about normal snow conditions in the different areas. The data were either from meteorological stations situated at the farm itself (Staur, Kleiva, and Rustefjelbma), or from the nearest meteorological station (shown in parentheses in Table 2). Sola is the representative station for Særheim and Rogaland stamsædgård, Fana for Stend, Trondheim for Skjetlein, and $\emptyset$. Tessa for Klonessetra. When 2 or more stations are listed, the value given is the mean for the observations from these stations. 


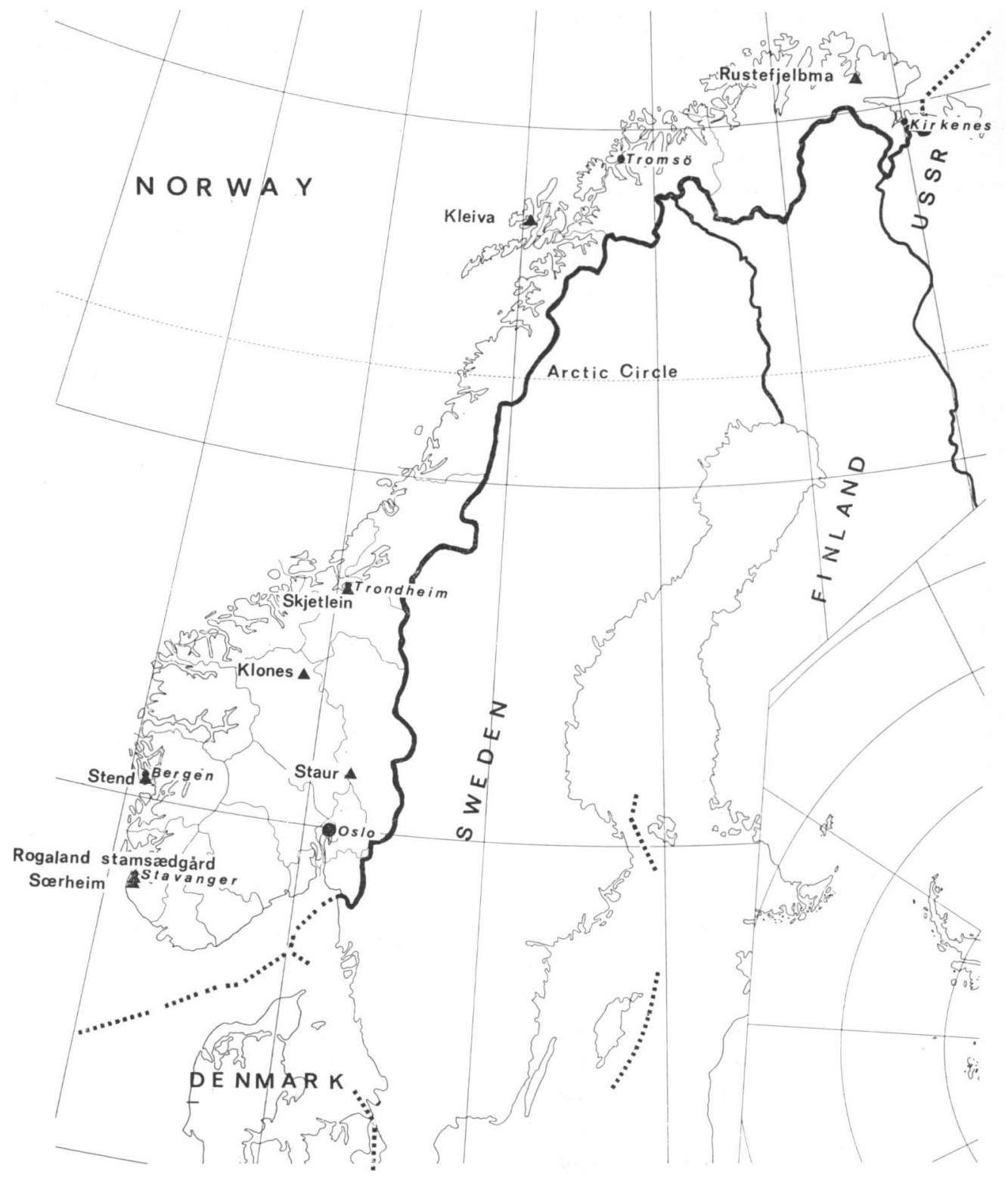

Figure 1. Map of Norway with the geographical location of the farms. 


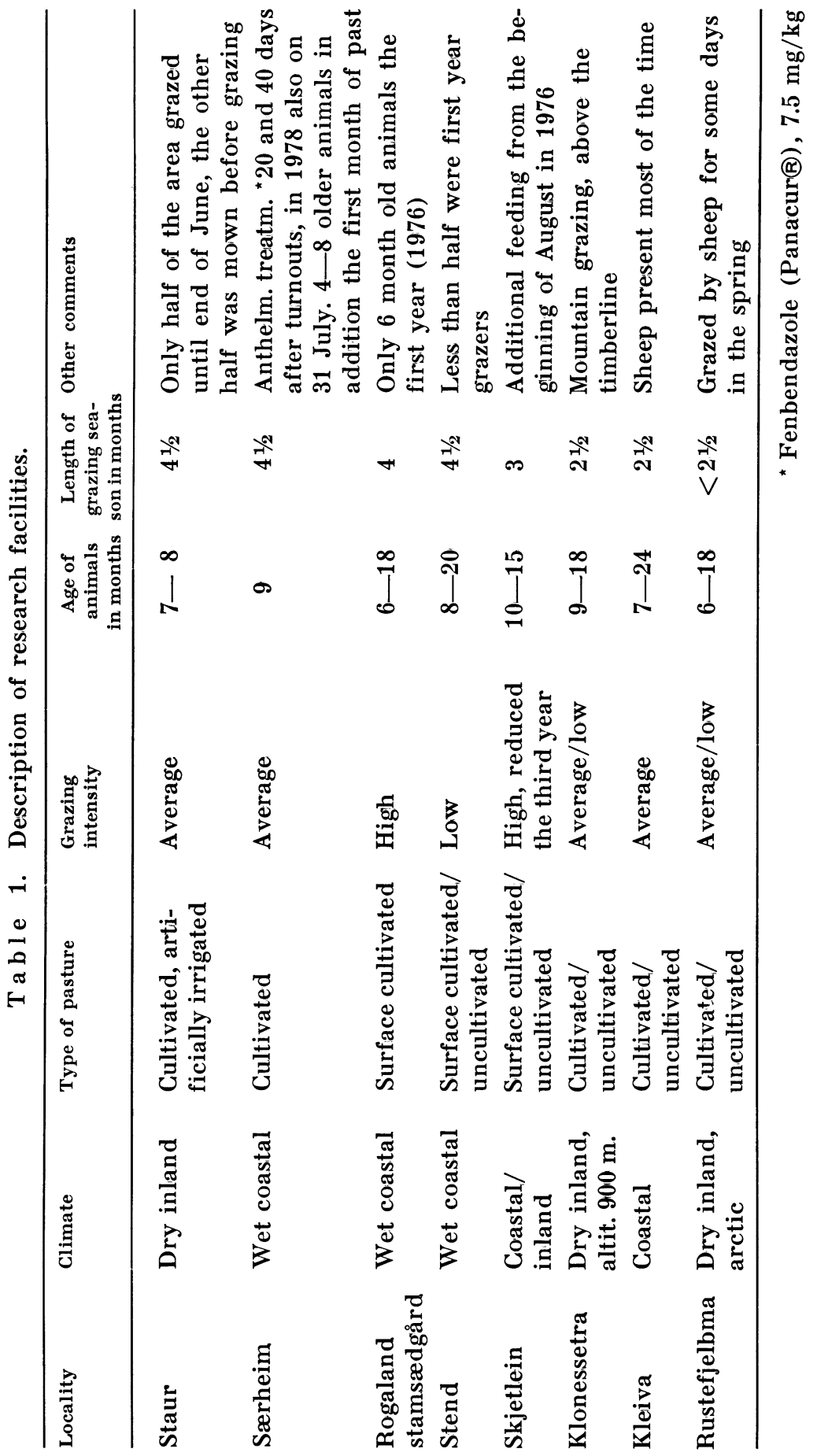




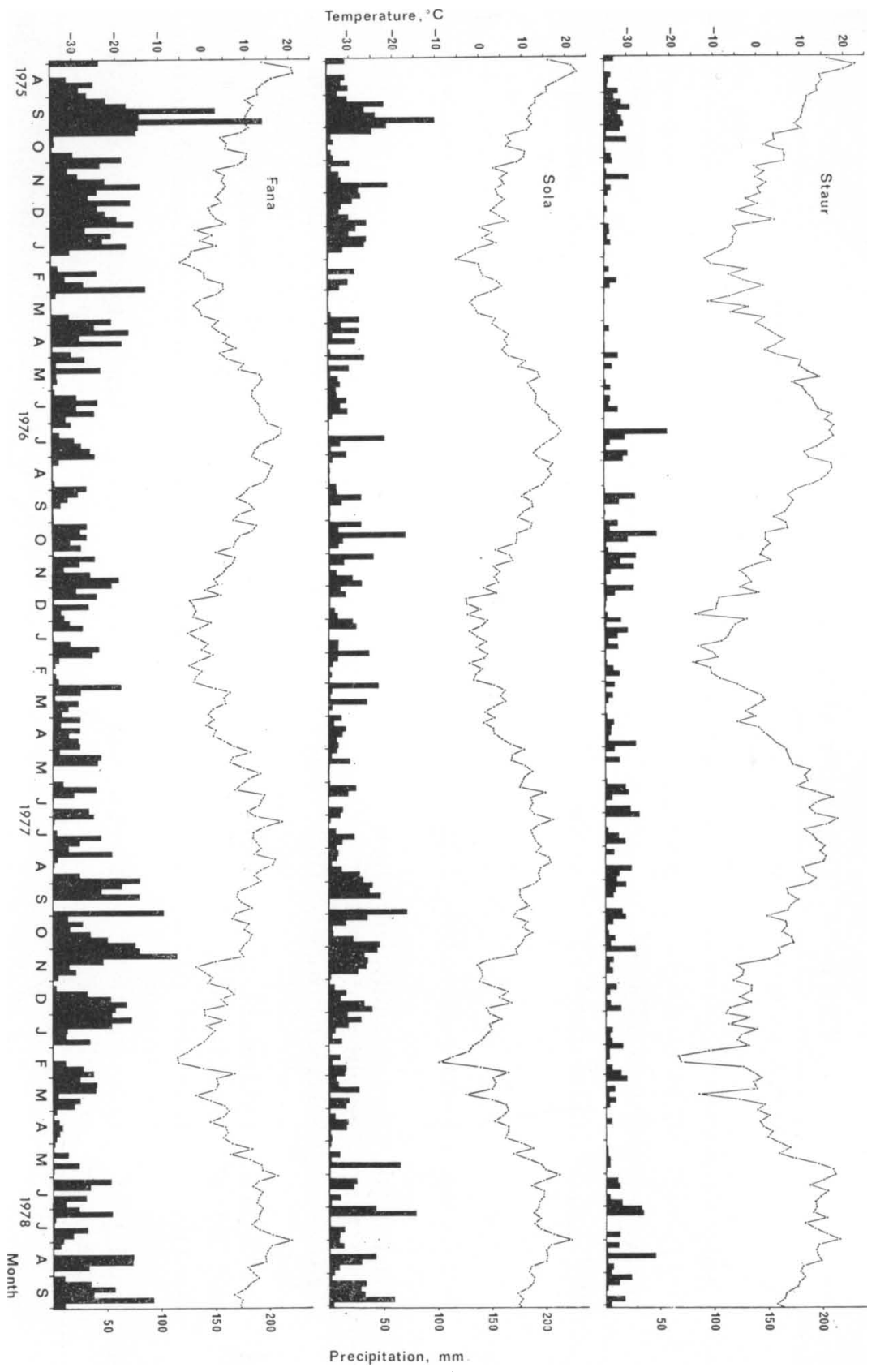

F ig u r e 2. Five-day means of temperature (curves, in ${ }^{\circ} \mathrm{C}$ ) and five-day sums of precipitation (black columns, in $\mathrm{mm}$ ). 


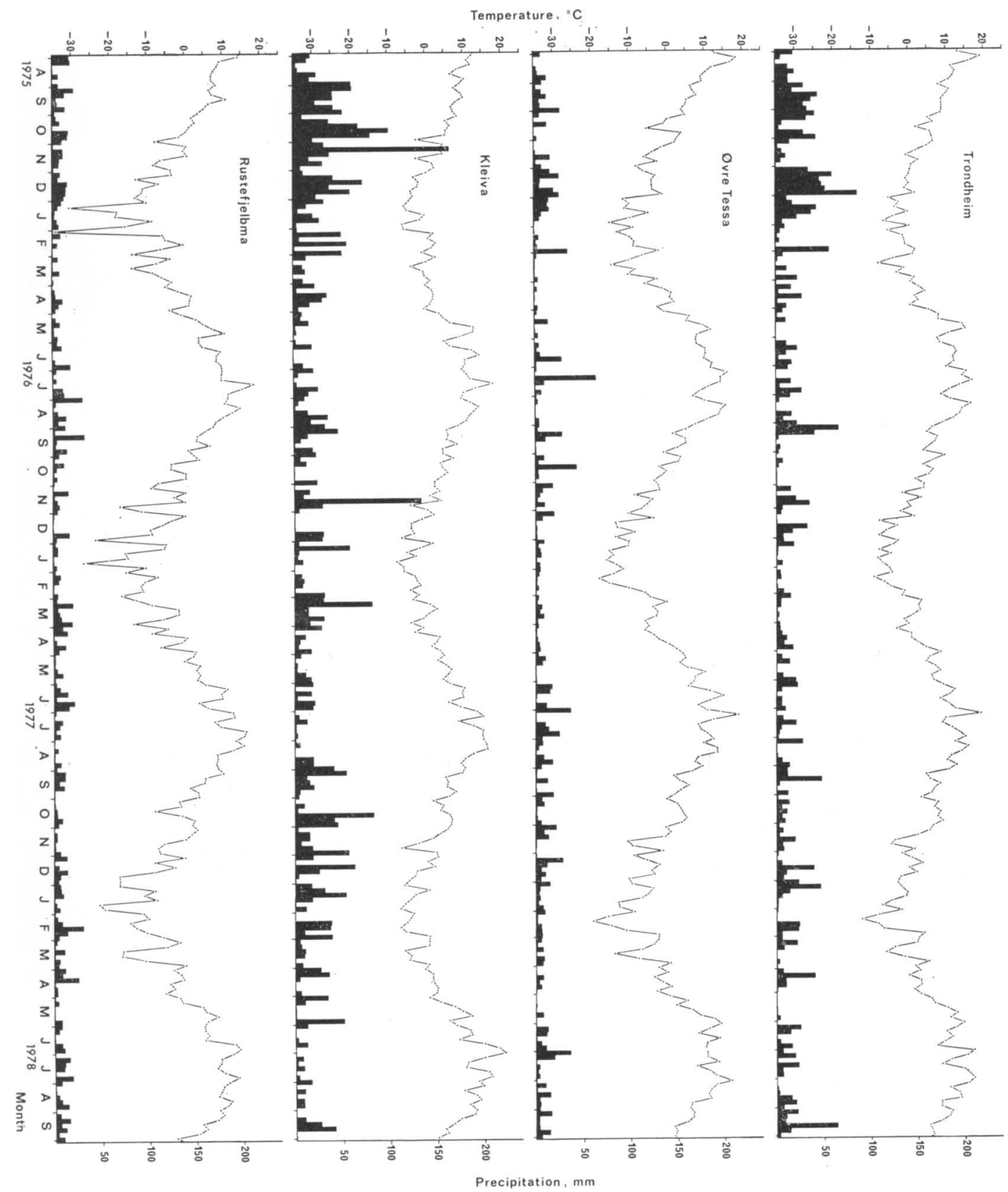



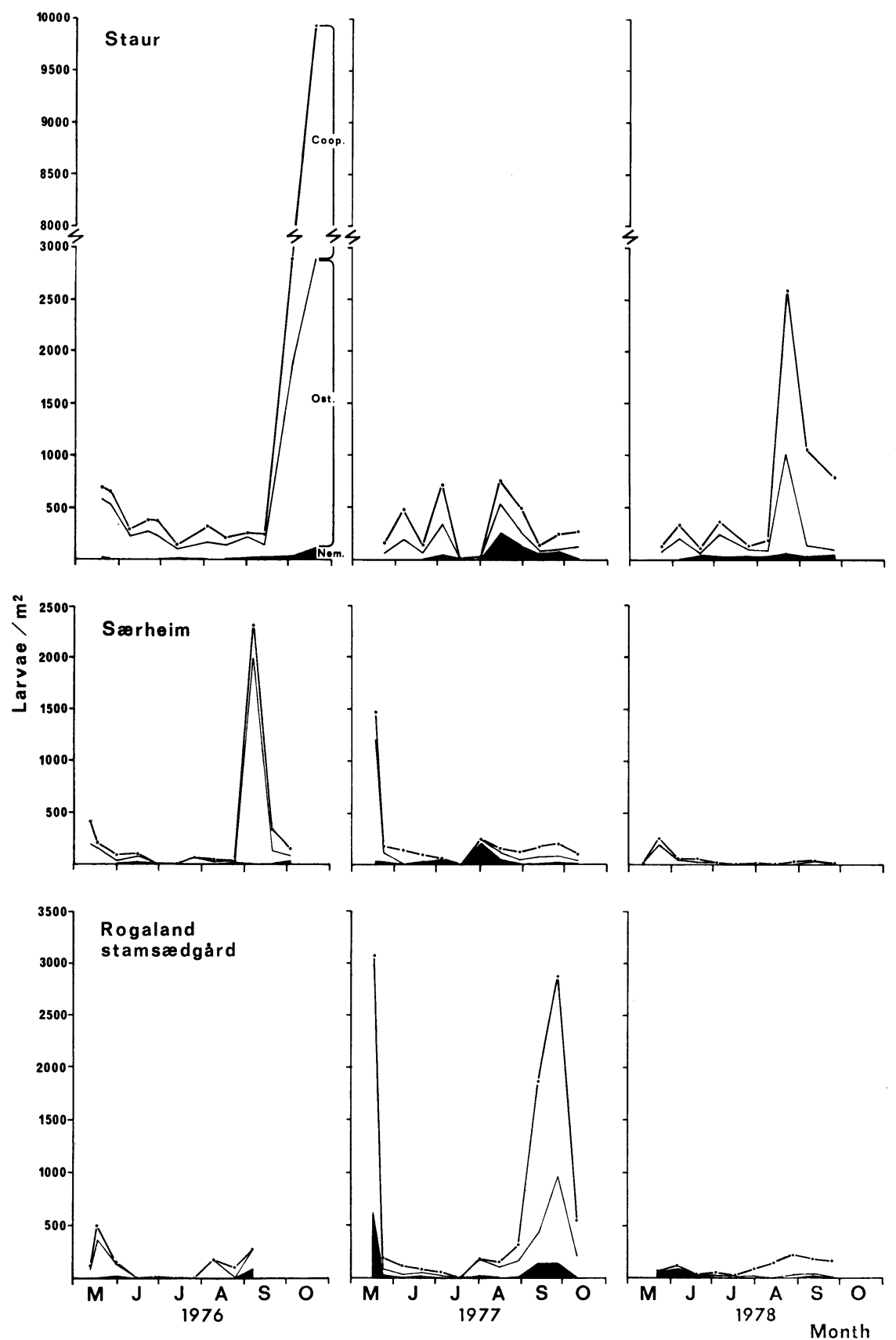

F i g u re 3. The number of infective larvae per $\mathrm{m}^{2}$ of pasture. The upper line (- - represents the total number of trichostrongylid larvae, the relative distribution of Ostertagia, Cooperia and Nematodirus as shown for Staur 1976. Ost. = Ostertagia spp., Coop. = Cooperia spp., Nem. $=$ Nematodirus spp. 
Epidemiological investigations

171
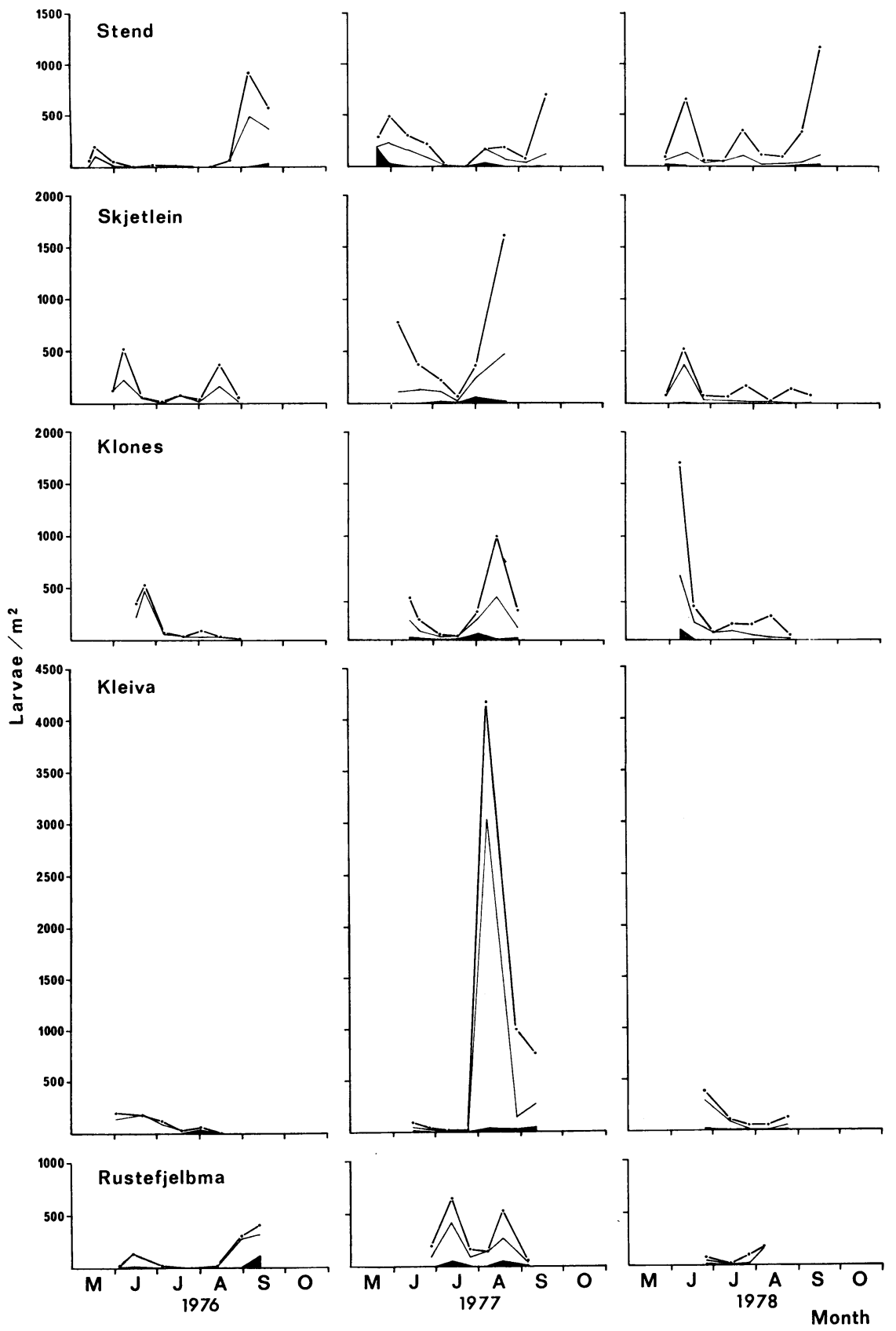


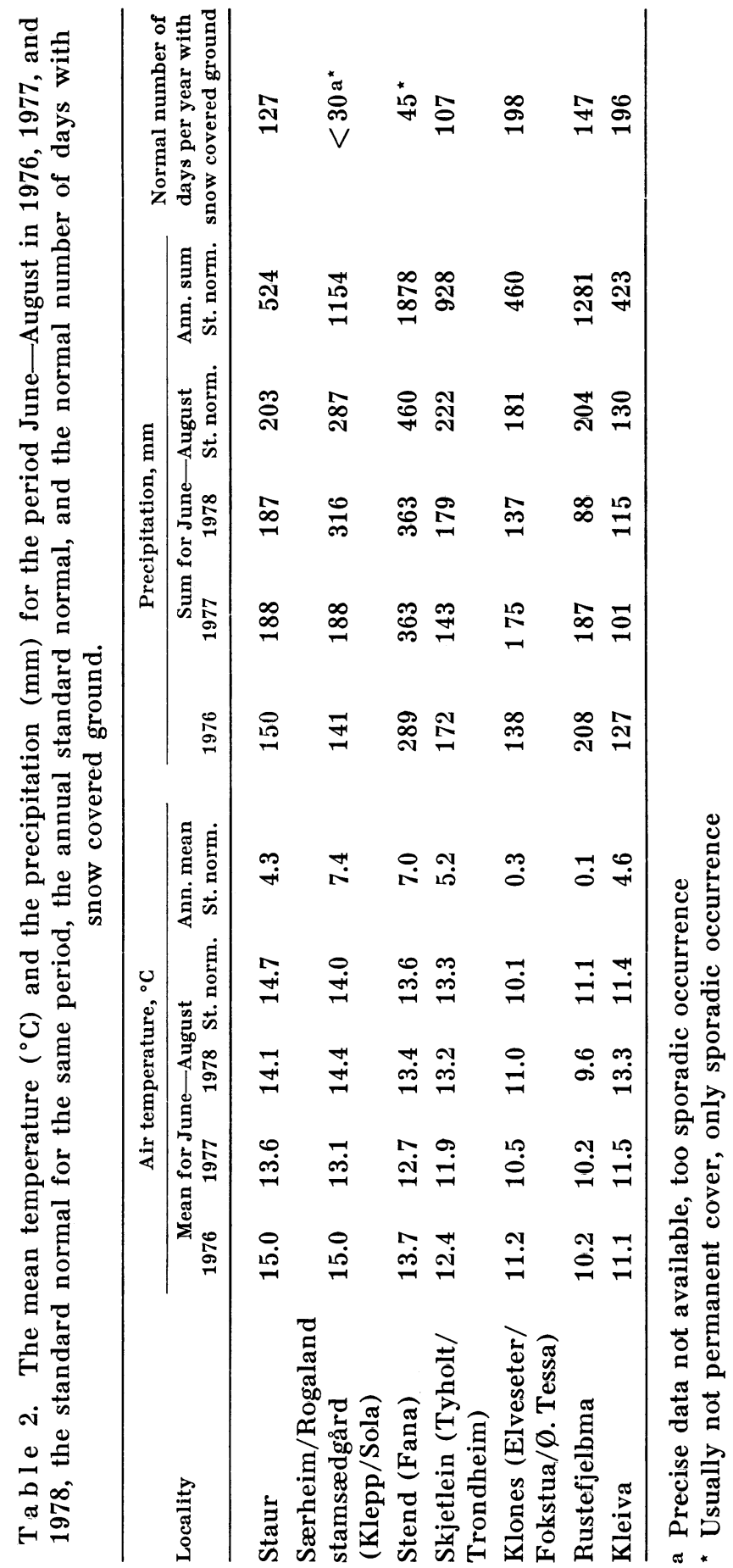


The past u res varied more than was desirable. Table 1 describes the type of pasture, stocking rate, and the length of the grazing season. The size of the grazing areas varied between 0.5 and $5-6$ ha.

The a n i a ls were Norwegian Red Cattle, the most common dairy breed in Norway. The number of first year grazers varied between 10 and 20, except in 1978 at Skjetlein, where it was reduced because of poor results in the 2 previous years. At all places except Staur, mixed grazing with some older cattle was practiced, sometimes even sheep, and occasionally a few horses (Kleiva). Further comments on this are given in Table 1.

A $\mathrm{nthe} 1 \mathrm{mintictreat} \mathrm{ment}$ (Fenbendazole*, $7.5 \mathrm{mg}$ / $\mathrm{kg}$ ) was given at Særheim, because the animals in question were also part of another investigation. See Table 1 for details.

F a e c a l s a m p l e s were as a rule collected every fortnight from the ground, samples being selected from as freshly deposited faecal pats as possible. The number collected was $10 \%$ of the number of animals present plus 2. At Staur and Særheim, however, the samples were collected from the rectum of all the animals on every other sampling date. The samples were examined by a modified McMaster-technique by Helle (1964). Differential egg counts were made for Nematodirus helvetianus, Trichuris sp. and the common trichostrongylid eggs.

$\mathrm{H}$ e $\mathrm{rb}$ a g e ex a m i n a $\mathrm{t}$ i o $\mathrm{n}$. Grass samples were collected fortnightly, extra samples being taken 1 week after turnout in 1976. They were collected as decribed in an earlier investigation (Tharaldsen 1976), and consisted of 200 small samples of approximately $10 \mathrm{~cm}^{2}$ each from each pasture, $0.2 \mathrm{~m}^{2}$ in all. The larvae were recovered following the method described by Henriksen (1974). Not all the grass collected from each pasture was processed, but after a thorough mixing and weighing, 2 samples of $250 \mathrm{~g}$ each were taken out and washed, and the mean number of infective larvae from these 2 were used to calcuiate the number of larvae per $\mathrm{m}^{2}$.

\section{Pasture larval counts}

\section{RESULTS}

Fig. 3 shows the results of the herbage examination.

* Fenbendazole (INN), Panacur $®$ 

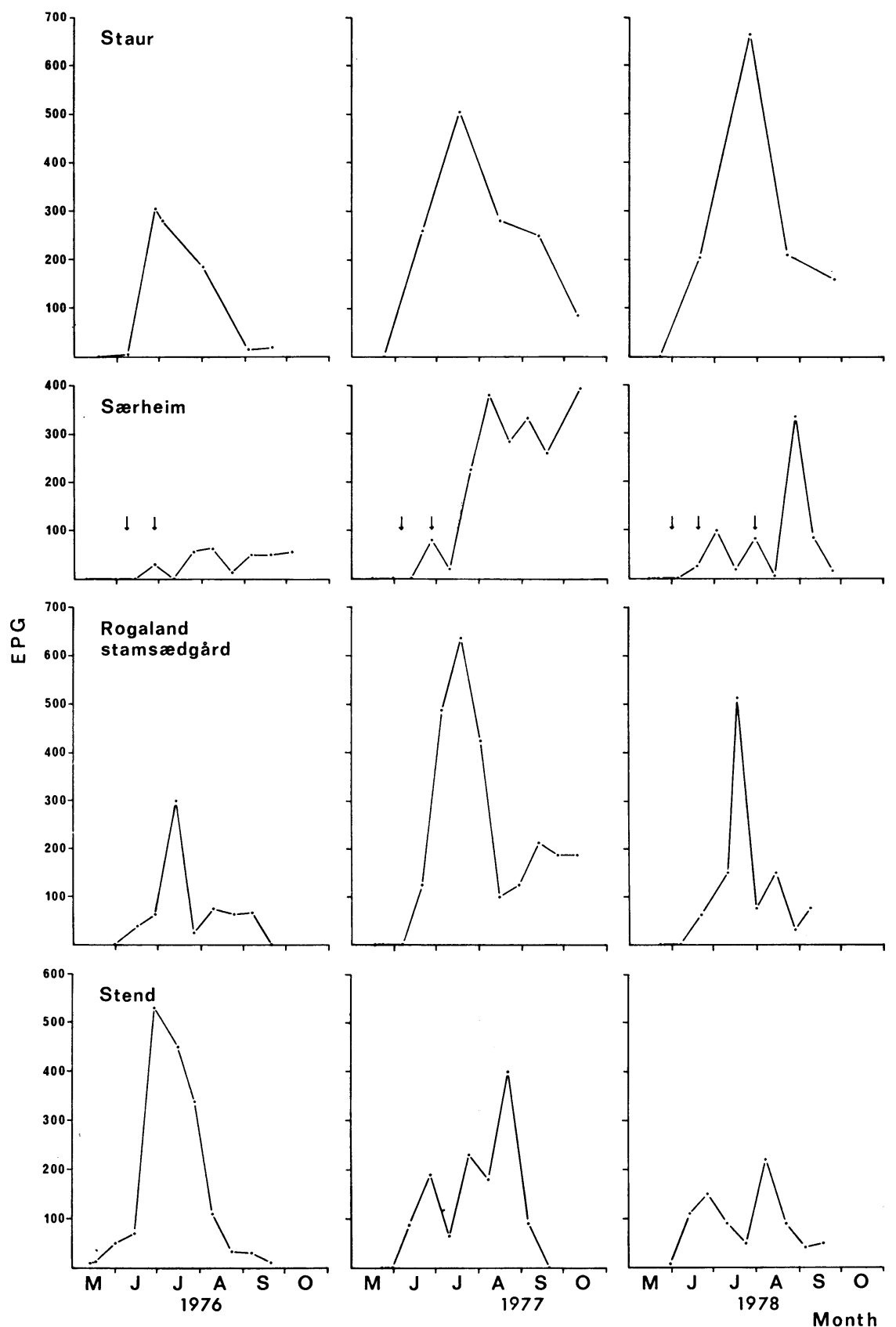

F i g u r e 4. Mean faecal egg counts (EPG). The arrows in the figures from Særheim show when anthelmintic treatment was given. 
Epidemiological investigations

175
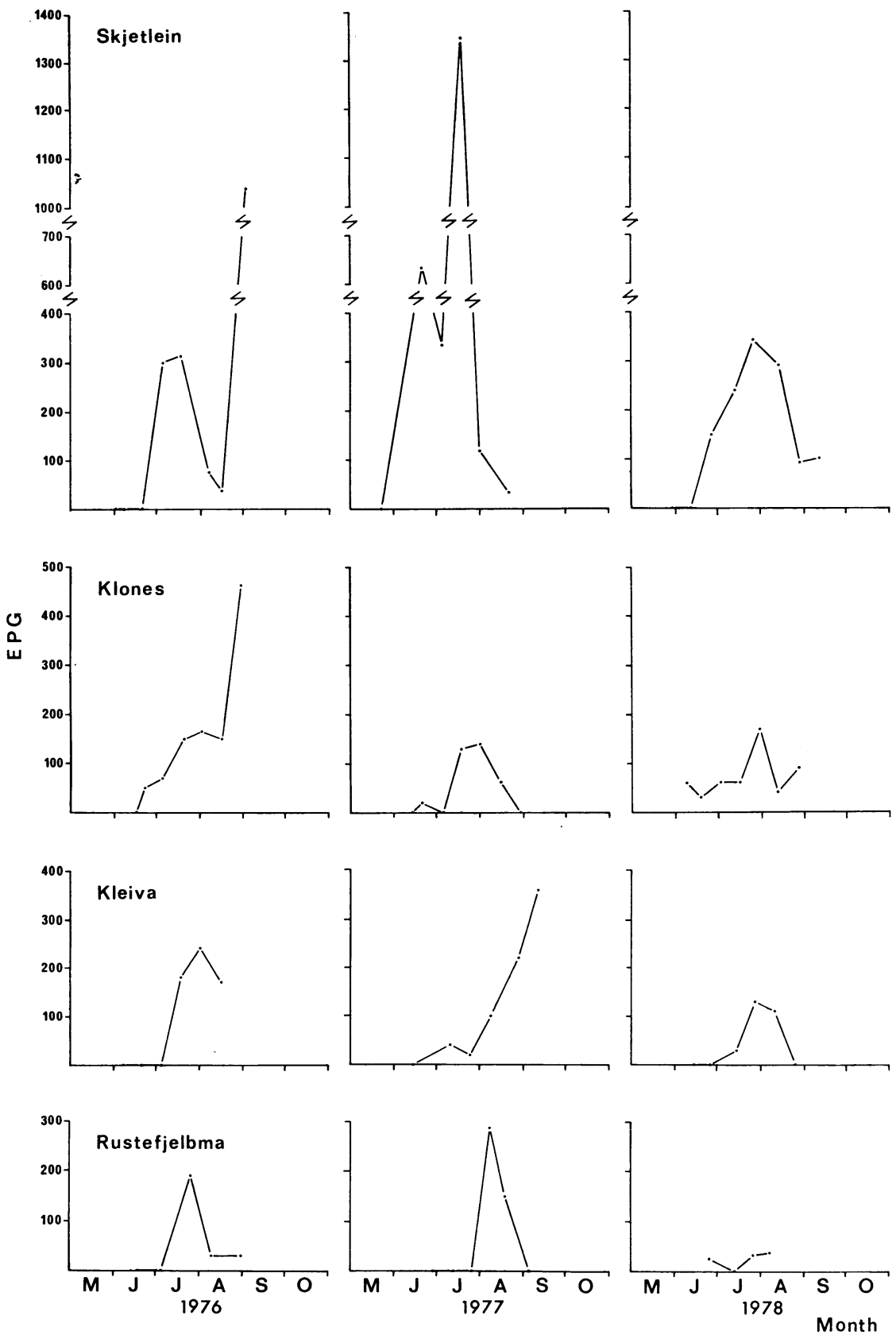
Th e n e m a t o d e s p e i e s. Ostertagia spp., Cooperia spp. and Nematodirus sp. were found in all the areas; Ostertagia and Cooperia were the dominant species. Most years, there seemed to be a higher proportion of Ostertagia in the spring, but more of Cooperia in the autumn.

Winter survival. There was always a certain number of larvae present in the spring, though the number varied from place to place, and from one year to another at the same place. In some years, the pasture larval counts were very high in the spring, as seen at Særheim and Rogaland stamsædgård in 1977, and Klones in 1978.

Variations through the summer. The larval counts did not show any stereotype seasonal pattern from year to year at the same farm, nor from place to place within the same year. The only constant finding seemed to be that the larval counts were at their lowest sometime in July. There was no obvious correlation between the larval counts seen in the spring and those seen in the autumn at the same farm, or between the numbers found in the spring compared with the results from the preceding autumn. The peak larval counts were sometimes found in the spring, but equally often in the autumn. Rustefjelbma, in the very far north, was the only place where larval counts never exceeded $1000 / \mathrm{m}^{2}$. At Rogaland stamsædgård in 1976, we have no observations from the pasture after the begining of September that year, when the animals were moved to another pasture which had not been grazed by cattle since the previous year. Larval count from this new area shortly afterwards was $1609 / \mathrm{m}^{2}$, about $80 \%$ of these larvae being Ostertagia.

\section{Faecal egg counts}

Results are sown in Fig. 4. The egg counts were mostly zero when the animals were turned out. A few eggs were seen at Klones and Rustefjelbma in 1978, but these could have been deposited in the faeces from some older animals, which also grazed here.

Maximum egg counts were usually seen about $1 \frac{1}{2}$ months after turnout, except at Skjetlein and Klones in 1976, and Kleiva in 1977, when the peaks were observed at the end of the season. The egg counts from Særheim must be evaluated in the light of the anthelmintic treatment given. 
Generally, egg counts were lower in the cooler areas, i.e. the mountain pasture at Klones, and the 2 most northern places.

Egg counts exceeding 1000 EPG (eggs per $g$ of faeces) were only seen at Skjetlein. Here even large numbers of coccidia were registered simultaneously with the peak egg counts in 1977.

\section{Clinical symptoms}

Clinical symptoms of gastrointestinal parasitism were obvious only at Skjetlein in 1976 and 1977. In 1977 the animals were so severely affected that, to save their lives, they had to be treated with anthelmintic at the end of July. Two animals were housed for the rest of the summer.

\section{DISCUSSION}

Experimental conditions. Although all the farms in this investigation were owned by institutions, and generally larger than the average commercial farm in Norway, they must be considered as being relatively typical for the particular region, and thus comparable. The pastures, however, varied more than was desirable, both in quality and in grazing intensity, and the age of the animals was not completely homogenous, as seen from Table 1; this may have obscured some of the effects of the climatic factors.

The $\mathrm{meth}$ od $\mathrm{s}$ in this investigation were the ones usually employed in parasitological studies, but with some minor modifications. Faecal samples were only collected from a limited number of droppings from the ground. Egg counts are not quite representative for the parasite burden of the animals, but must be considered useful when making comparisons between the various areas. Pasture larval counts are usually expressed as the number of larvae per $\mathrm{kg}$ grass, but in this investigation we have chosen to use the number of larvae per $\mathrm{m}^{2}$, to avoid the dilution effect of variable grass growth. Most of the time, however, these counts were at about the same level.

Parasite s pecies. The investigation shows that there are relatively few species of gastrointestinal nematodes in cattle in Norway, and that the same species are found all over the country. Ostertagia ostertagi and Cooperia oncophora are the two dominant species, while other species belonging to these genera and Nematodirus helvetianus are present to a lesser 
extent. In other experiments at Staur (unpublished), a small proportion, $1-2 \%$, of Grosspiculagia (Ostertagia) lyrata has been found at necropsy, and a somewhat higher percentage of Cooperia memasteri (Helle \& Tharaldsen 1976). Small numbers of Trichuris sp. are also regularly seen, and eggs of Strongyloides are occasionally found in faecal samples.

Winter s u rvival. The most important characteristic of all these species is the ability of their free-living stages to survive the winter on the pasture. This seems to be the case in all the places that were studied, in spite of considerable variations in the climate, which is mild and humid on the south-west coast, dry and cool, but with warmer summers in the south-east, and arctic in the very north and in the mountain regions.

Fig. 2 shows no marked differences in the survival capability between the areas. In some cases, relatively high counts were seen in the spring after a preceding autumn with high larval counts, e.g. Særheim in 1977. At Rogaland stamsædgård, counts were even higher than at Særheim in the same spring, which seems contradictory, since the counts there were quite low the previous autumn. At Rogaland stamsædgård, however, the animals were moved to another pasture in the middle of September, and grass analyses were not performed after that date. Any rise would therefore not have been registered. On the other hand, high counts at Staur in $\mathbf{1 9 7 6}$ did not lead to heavy intial contamination in 1977, and similarly at Rogaland stamsædgård, the build-up in the autumn of 1977 was followed by a very moderate contamination in $\mathbf{1 9 7 8 .}$

The tendency towards dominance of Ostertagia in the spring in most instances, in spite of the higher proportion of Cooperia in the autumn, could indicate a somewhat better survival capability of Ostertagia under Norwegian conditions.

Permanent snow-cover has been considered very important for the survival of the free-living larvae through the winter. Our results do not indicate that this alone is responsible for good survival, since high larval counts in the spring were seen on the one hand both at Særheim and Rogaland stamsædgård, which have relatively mild winters and hardly any snow cover most years, and on the other hand at Skjetlein and Klones, where the ground is solidly covered with snow for long periods. However, at Klones, which has snow cover for more than half of the year, 
the spring contamination in 1978 was one of the highest recorded in this investigation in early summer.

In more temperate areas, such as most of Europe south of Norway, the regular pattern seems to be that the surviving larvae are too few to cause immediate harm, but eventually result in a much higher pasture contamination in July, which can then be deleterious to cattle which have not yet developed sufficient immunity (Michel et al. 1970). Previous studies in this country, however, have shown that, at least in south-eastern Norway, the spring contamination at comparable levels to those seen in this investigation is usually extensive enough to affect young cattle, producing weight loss and in some years also pronounced clinical symptoms during the first weeks at pasture (Tharaldsen 1970, 1976, Helle \& Tharaldsen 1976). Similar results have also been found in Sweden, a country with comparable climatic conditions (Nilsson \& Sorelius 1973).

Larval counts: Variations during the summ e r. The generally accepted pattern of larval infestation on herbage during the summer has been described by Michel (1976 a, b). In spring there are usually low numbers of overwintering larvae, which rapidly decline to near zero. From July onwards there is a new build-up, derived from eggs in the faeces of the grazing animals, and maximum counts are seen in the autumn. Slight departures from this pattern are likely to be seen in very wet and very dry summers. During dry summers, levels on herbage may remain low, but with large faecal reservoirs, while wet weather favours the emergence of larvae, but also depletes the reservoirs more quickly.

There were many deviations from the standard pattern in this investigation. In some cases, e.g. at Rogaland stamsædgård in 1976, lack of sampling in the autumn gave an incomplete picture of the larval curves. Fig. 2 shows, however, that the number of eggs in most places was large enough to envisage high larval counts in the pasture in the autumn. In spite of this, there were in some places, few larvae in the autumn, a situation which may have been due to such factors as climate, length of the grazing period, and different management practices.

The effect of temperature on the development of the larvae is not easily seen in this investigation. The mean annual temperature in the various parts of the country differs greatly, being as 
low as $0.1^{\circ} \mathrm{C}$ at Rustefjelbma, $0.3^{\circ} \mathrm{C}$ in the mountain area of Klones, and $7.4^{\circ} \mathrm{C}$ for Særheim (Table 2). The summer temperature is more likely to be of importance for larval development, and this figure may differ from the annual mean. The annual means for Kleiva and Staur were nearly the same, but during the stmmer months Kleiva had a mean temperature $3.3^{\circ} \mathrm{C}$ below that for Staur. The summer temperature did not differ much from the normal during this investigation, except at Rustefjelbma in the far north, which had subnormal temperatures in all 3 years, and at Klones, where it was above the normal in all the years concerned. With the exception of Kleiva in 1977 and to some extent Klones, there were generally small numbers of larvae in the autumn at Rustefjelbma and Kleiva in the north, and the mountain area at Klones. On the lowland pastures in southern Norway, there was no regular pattern which could be attributed to the summer temperature.

The low larvae counts in the north were not necessarily the result of low temperature only, as the grazing period is also very short here. This may reduce the likelihood of the larvae reaching the infective stage within the grazing season, which is only $2-2 \frac{1}{2}$ months in the coldest regions, see Table 1 . In comparison, the grazing period in the lowland areas in the south is $4 \frac{1}{2}$ months.

The mean annual precipitation differs markedly from place to place, varying from an extremely low figure at Rustefjelbma (only $423 \mathrm{~mm}$ ), to 4.5 times this figure at Stend. Precipitation during the summer months was subnormal in all 3 years at all the places, except Særheim/Rogaland stamsædgård and Stend in 1978, and at Kleiva in 1976. In 1976, precipitation varied from 49 to $77 \%$ of the normal values for all places except Kleiva and Rustefjelbma in the north. It is difficult to see any clear correlation between precipitation and the number of larvae in the pasture during the latter part of the grazing period.

In spite of low precipitation, high larval counts were occasionally found in the autumn, for instance at Staur and Særheim in 1976, and at Rogaland stamsædgård in 1977. On the other hand, there were low numbers at Rogaland stamsædgård in 1978, in spite of the summer being extremely wet. Neither precipitation nor temperature easily explain the high larval counts at Kleiva in August, 1977. Such counts were not seen there the previous year, in spite of the weather being very much the same 
in both years. Though one would have expected higher larval counts at Stend, with its mild and wet climate and long grazing season, the low figures are probably to be explained by the very low stocking rate. Stend is, however, the place at which larval counts in the 3 years showed the most regular pattern.

At Staur artificial irrigation was practised to a limited extent in mid-summer, which means that the relevant precipitation figures in Table 2 are on the low side. However, previous experiments performed there, showed that such irrigation does not seem to have any significant effect on the free-living stages of trichostrongylids (Tharaldsen 1976).

The deviating pattern in the larval counts of Særheim and Rogaland stamsædgård are partly to be explained by the use of anthelmintics at Særheim.

The relatively large numbers of Ostertagia larvae at Rogoland stamsædgård in the middle of September 1976, on a pasture which had not been grazed since the previous summer were surprising. Al Saqur et al. (1982) have recently shown that Ostertagia larvae from cattle could be present for more than 1 year in the soil, and in the absence of any new contamination, the larvae could migrate upwards and result in larval counts in July and August similar to those seen the previous autumn. The findings at Rogaland stamsædgård confirm this phenomenon, and similar observations have been seen at Staur in other experiments not yet published.

The relatively higher proportion of Cooperia observed in most instances in the autumn, is probably the result of somewhat lower temperature requirements for the development of Cooperia (Levine 1963) compared with Ostertagia (Pandey 1972a).

In most of the places in this investigation, there seems to be a somewhat different pattern in the occurrence of the free-living stages of the cattle trichostrongylids from that seen further south in Europe, where the larval build-up from July onwards is most important for the development of clinical symptoms. In Norway the larval build-up later in the summer may also be of importance as a cause of disease in some years, but it seems, however, that the autumn rise often comes so late in the season that the influence on the animals is less than expected. The main significance of the larvae being present in the pasture in the autumn seems to be that they provide a source of overwintering larvae, which may attack young cattle the next spring. 
In Great Britain, uptake of larvae of Ostertagia ostertagi in the autumn often results in inhibition of the development of the larvae, so that maturation is delayed until the next spring (Armour et al. 1969). Such inhibition is considered to be an important factor for the transmission of Ostertagia from one grazing season to the next. Inhibition of Ostertagia has not yet been proven to be important in Norway. In Australia, Smeal \& Donald (1982) have found that there are differences between beef and dairy cattle populations of Ostertagia ostertagi, with significantly lower proportions of inhibition in larvae of dairy cattle origin. This is explained by differences in management of the 2 cattle populations. On dairy farms, first year grazers are usually kept on special calf pastures, separated from the majority of the older cattle. As a result, inhibition of larvae in older cattle will be of no importance for the infection of the first year grazers, which are mainly exposed to larvae which have survived from the previous season. Such a management practice is common also in Norway. With good winter survival, the calves will be infected when they are most susceptible. With short summers, an early infection gives a better chance for the free-living stages to develop into the infective one, the stage which best can survive the winter on the pasture. Under these circumstances, one could expect a selection of parasite strains with a high capacity for winter survival.

Eg g c o u n t s. Egg counts were mostly at a moderate level, with a peak in mid-summer, and a fall in the autumn, which is the usual pattern seen in young cattle on pasture. At some of the places, where the grazing period was very short, the sampling period was also so short that there was insufficient time to register the expected fall in the egg counts. Otherwise, the most marked deviations were seen at Særheim, where the animals received anthelmintic treatment, and at Skjetlein in 1976, where high egg counts were seen at the end of the grazing season. Skjetlein was also the place were the highest egg counts were registered; on that farm, the stocking rate was very high the first 2 years. With a high stocking rate, animals will be forced to graze closer to the faecal pats, where the contamination is much higher (Hansen et al. 1980).

Maximum egg counts were mostly below 1000 EPG, the figure often considered to be indicative of a clinically manifest tricho- 
strongylid infection (e.g. Dunn 1978). During trials lasting several years at Staur, however, there have been significantly reduced weight gains every year in young cattle on permanent pasture compared with animals on parasite-free ground (Tharaldsen 1978). Even with mean maximum egg counts as low as $305 \mathrm{EPG}$, growth reduction was $24.7 \mathrm{~kg}$ one summer. This reduction is closer to the weight losses seen in experimentally infected calves which were given a dose of Ostertagia/Cooperia larvae expected to produce clinical parasitism, than that seen in subclinically infected animals (Randall \& Gibbs 1981). The results in this investigation thus indicate that the parasites may be responsible for reduced weight gains in most places, but perhaps to a lesser extent in areas such as Klones, Kleiva, and Rustefjelbma, where the summer season is short.

There were many variations and deviations from the standard pattern in this investigation, but generally there seemed to be higher larval counts in the southern, warmer parts of the country, (Staur, Særheim and Rogaland stamsædgård). Occasionally, however, larvae were found in such large numbers in spring or autumn that they might have interfered with the health and growth of young cattle also in the other regions. Rustefjelbma, in the far north, was the only place where larval counts from the pasture and faecal egg counts were consistently low in all 3 years. The main reason for this is probably a combination of low summer temperature, low precipitation, and a very short grazing season. Even in this case, however, one should be careful not to generalize from the results, as the summer temperature was markedly below average in all 3 years studied. Precipitation was also slightly lower than the normal.

\section{CONCLUSION}

The investigation has shown that gastrointestinal nematodes are found in cattle all over the country. The free-living stages of the parasites were able to survive the winter on the pasture to a large extent in all areas despite considerable climatic variations. The winter survival rate of the infective larvae of Ostertagia seemed to be higher than for Cooperia. Faecal egg counts and herbage larval counts through the grazing season varied greatly from year to year in each area, and there were also great differences between the various places observed. The material did 
not show any definite correlation between climate factors, such as precipitation and temperature, and the occurrence of eggs in faeces or the number of larvae in the herbage. It seems likely, though, that the free-living stages will be more affected by the summer climate than by the climate during the rest of the year. Neither was it possible to demonstrate any effect of the duration of the snow cover in winter on the number of larvae on the pasture.

The lowest counts of both eggs in the faeces and larvae on the pasture were seen in Finnmark, in the very north of Norway. This is most likely due to low summer temperature combined with very low precipitation and a short grazing season, 21/2 months or less. The chance of disease due to parasites thus seems less here. Sufficiently high counts of infective larvae in herbage were otherwise occasionally seen, indicating that given the right conditions, parasite problems might arise, with economic losses as a result. Important factors would presumably be the age of the animals, and the stocking rate. Overt clinical disease due to parasites was only seen at one of the places, where the herbage larval counts were relatively moderate, but the stocking rate too high.

\section{ACKNOWLEDGEMENTS}

We are indebted to all those who assisted us at the agricultural schools at Klones, in Finnmark, at Kleiva, Skjetlein, and Stend. We thank the Norwegian Grain Corporation for allowing us to use their research farm at Staur, and the Institute of Animal Nutrition at the Agricultural University of Norway for providing us with animals. The assistance from the staff at Staur, at the State research farm at Særheim, and at Rogaland stamsædgård is greatly appreciated. We also thank Jorun Marie Olsen and Hanne Elisabeth Møller for technical assistance at the laboratory.

This work was supported by grants from the Agricultural Research Council of Norway.

\section{REFERENGES}

Al Saqur, I., K. Bairden, J. Armour \& G. Gettinby: Population study of bovine Ostertagia spp infective larvae on herbage and in soil. Res. Vet. Sci. 1982, 32, 332—337.

Armour, J., F. W. Jennings \& G. M Urquhart: Inhibition of Ostertagia ostertagi at the early fourth larval stage - II. The influence of environment on host or parasite. Res. Vet. Sci. 1969, 10, 238244. 
Dunn, A. M.: Veterinary Helminthology. 2nd ed. William Heinemann Medical Books Ltd. London 1978, 323 pp.

Hansen, J. W., P. Nansen \& J. Foldager: The importance of stocking rate to the uptake of gastrointestinal nematodes by grazing calves. In Epidemiology and Control of Nematodiasis in Cattle. Ed. by Nansen, P., R. J. Jørgensen \& E. J. L. Soulsby, Martinus Nijhoff Publishers, The Hague 1980, p. 471-494.

Helle, O.: Coccidiose hos sau. (Coccidiosis in sheep). Medlemsbl. norske Vet.-foren. 1964, 16, 117-127.

Helle, $0 . \& J$. Tharaldsen: Gastrointestinal parasites in young cattle in Norway. Vet. Parasit. 1976, 1, 345-357.

Henriksen, S. Aa.: Parasitologiske græsmarksunders $\varnothing$ gelser i Danmark. (Parasitological examinations of pasture in Denmark). Proc. 12th Nord. Vet. Congr. Reykjavik 1974, p. 83-84.

Levine, N. D.: Weather, climate, and the bionomics of ruminant nematode larvae. Advanc. vet. Sci. 1963, 8, 215-261.

Michel, J. F., M. B. Lancaster \& C. Hong: Field observations on the epidemiology of parasitic gastroenteritis in calves. Res. Vet. Sci. 1970, 11, 255-259.

Michel, J. F.: Nematode infections in grazing animals. Advanc. Parasit. 1976 a, $14,355-397$.

Michel, J. F.: The hazard of nematode infection as a factor in the management of cattle. ADAS Quart. Rev. $1976 \mathrm{~b}, 20,162-177$.

Nansen, $P$. (Editor) : Kvægets mave-tarm parasitter. (Gastrointestinal parasites of cattle). Final report, NKJ-Project No. 36, 1981, $125 \mathrm{pp}$.

Nilsson, O. \& L. Sorelius: Trichostrongylidinfektioner hos nötkreatur i Sverige. (Trichostrongyle infections of cattle in Sweden). Nord. Vet.-Med. 1973, 25, 65-78.

Pandey, V.S.: Effects of temperature on development of the free-living stages of Ostertagia ostertagi. J. Parasit. 1972 a, 58, 1037-1041.

Pandey, V. S.: Effect of temperature on survival of the free-living stages of Ostertagia ostertagi. J. Parasit. $1972 \mathrm{~b}, 58,1042-1046$.

Persson, L.: Studies on the survival of eggs and infective larvae of Ostertagia ostertagi and Cooperia oncophora in herbage. $\mathrm{Zbl}$. Vet.-Med. B 1974, 21, 787-798.

Randall, R. W. \& H. C. Gibbs: Effects of clinical and subclinical gastrointestinal helminthiasis on digestion and energy metabolism in calves. Amer. J. vet. Res. 1981, 42, 1730-1734.

Smeal, M. G. « A. D. Donald: Inhibited development of Ostertagia ostertagi in relation to productions systems for cattle. Parasitology $1982,85,21-25$.

Tharaldsen, J.: Nematodes in young cattle on permanent and new pastures. Proc. 4th Symp. Scand. Soc. Parasit. Oslo 1969. In Nytt Mag. Zool. 1970, 18, 106.

Tharaldsen, J.: The epidemiology of trichostrongylid infections in young caitle in Norway. Acta vet. scand. 1976, 17, Suppl. 61, $21 \mathrm{pp}$. 
Tharaldsen, J.: Estimated losses due to gastrointestinal nematodes in young cattle in Norway. Proc. 4th Int. Congr. Parasit. Warzaw 1978, p. 175.

\section{SAMMENDRAG}

Epidemiologiske unders $\phi$ kelser av trichostrongylid infeksjon hos ungfe i ulike deler av Norge.

Forekomsten av mage-tarmnematoder hos ungfe i sin første beitesesong ble studert i relasjon til klima og geografisk lokalisasjon ved unders $\varnothing \mathrm{kelse}$ av grasprøver og fæces fra dyr fra 8 forskjellige gårder i 7 ulike deler av landet i løpet av tre beitesesonger. De vanligste artene var Ostertagia spp. og Cooperia spp. De infektive trichostrongylidelarvene var i stor utstrekning i stand til å overleve vinteren $i$ beitet på alle stedene som ble unders $\varnothing \mathrm{kt}$, og Ostertagia i st $\varnothing r r e$ grad enn Cooperia. Det var store variasjoner $i$ antall larver ved begynnelsen av beitesesongen, både fra sted til sted og fra år til år, men de lå ofte på et relativt $h \varnothing y t$ nivå. Unders $\varnothing$ kelsen bekrefter tidligere observasjoner, om at larver som har overvintret $i$ beitet ofte kan være en vesentlig årsak til tap. Klinisk utbrudd av parasittær gastroenteritt ble imidlertid bare observert en sommer på ett sted i denne unders $\varnothing$ kelsen.

De høye larvetallene som ofte ble funnet om høsten syntes i mindre grad å forårsake klinisk sykdom på den årstiden, da de antagelig opptrer for sent. De er imidlertid av stor betydning som kilde for den smitten som overvintrer $i$ beitet og som angriper ungfe neste vår.

Det var ingen tydelig sammenheng mellom larvetall i beitet og klimaet, bortsett fra at det synes å være høyere tall $\mathrm{i}$ de varmere delene av landet, der også beitesesongen er lengre. Det eneste stedet der både egg- og larvetall var gjennomgående lave alle 3 årene i denne unders $\varnothing$ kelsen var helt i nord, i Finnmark.

\section{(Received February 9, 1984).}

Reprints may be requested from: J. Tharaldsen, the Norwegian College of Veterinary Medicine, Div. of Parasitology, P. O. Box 8146 Dep., 0033 Oslo 1, Norway. 